\title{
PENGEMBANGAN DESA WISATA SIDOAKUR DALAM UPAYA PEMBERDAYAAN MASYARAKAT SIDOKARTO GODEAN, SLEMAN
}

\author{
Emmita Devi Hari Putri \\ NIDN. 0511018701 \\ Akademi Pariwisata BSI Yogyakarta \\ Email: emmita.evr@bsi.ac.id
}

\begin{abstract}
ABSTRAK
Indonesia merupakan suatu negara kepulauan yang memiliki beragam suku, ras dan budaya. Keanekaragaman tersebut membuat Indonesia menjadi negara yang kaya akan potensi wisata. Potensi wisata yang pada saat ini banyak diminati oleh wisatawan adalah wisata minat khusus. Wisata minat khusus adalah salah satu wisata yang belum lama dikembangkan di Indonesia. Wisata minat khusus yang saat ini sedang dikembangkan di Indonesia khususnya di Yogyakarta adalah desa wisata yang mana Yogyakarta merupakan sebuah kota yang memiliki berbagia potensi wisata alam seperti pantai, pegunungan, air terjun dan lain sebagainya. Desa wisata adalah sebuah kawasan pedesaan yang memiliki beberapa karakteristik khusus untuk menjadi daerah tujuan wisata. Penelitian ini adalah penelitian kualitatif deskriptifmenganalisis hanya sampai pada taraf diskripsi, yaitu menganalisis dan menyajikan fakta secara sistematik sehingga dapat lebih mudah untuk difahami dan disimpulkan.Teknik pengumpulan data yang digunakan adalah observasi, wawancara, dan dokumentasi.Penelitian ini menitikberatkan pada sebuah desa wisata yang berada di Kabupaten Sleman yaitu sebuah desa wisata Sidoakur yang terletak di desa Sidoakur, Kecamatan Godean, Kabupaten Sleman, Yogyakarta. Desa wisata Sidoakur ini memiliki potensi desa wisata budaya dan lingkungan dengan pemberdayaan masyarakat. Bentuk pemberdayaan masyarakat yang dilakukan desa wisata Sidoakur adalah melalui pengembangan desa wisata dengan dukungan pemerintah. Hasil dari penelitian adalah usaha pemerintah kabupaten sleman dalam pengembangan desa wisata Sidoakur melalui bantuan dana Program Nasional Pemberdayaan Masyarakat Mandiri (PNPM) Mandiri Pariwisata. Pemberdayaan masyarakat yang terlihat dalam pengembangan desa wisata Sidoakur yaitu usaha perbaikan, pengelolaan dan pengembangan penghijauan, SPAH (Sistem Penyimpanan Air Hujan), serta perikanan dan pertanian.
\end{abstract}

Kata kunci: desa wisata Sidoakur, pengembangan, pemberdayaan masyarakat.

\section{PENDAHULUAN}

Indonesia merupakan suatu negara kepulauan yang memiliki beragam suku, ras dan budaya. Setiap daerah tentunya memiliki keunggulan masing- masing sebagai identitas diri daerah tersebut. Hal ini tentunya sangat mendukung perkembangan pariwisata Indonesia. Banyaknya potensi alam yang dimiliki akan menarik wisatawan baik wisatawan lokal, nasional mau pun mancanegara untuk berkunjung ke Indonesia dan akan menguntungan bagi negara Indonesia itu sendiri.

Saat ini pariwisata dipandang sebagai sektor yang memberikan sumbangan dana dan sumber pendapatan terbesar bagi negara. Pada dasarnya pariwisata merupakan kegiatan yang dilakukan sementara, dilakukan suka rela tanpa ada paksaan untuk menikmati objek dan daya tarik wisata baik daya tarik wisata alam, 
daya tarik wisata budaya dan daya tarik wisata minat khusus. Pariwisata adalah aktivitas perjalanan yang dilakukan oleh sementara waktu dari tempat tinggal semula ke daerah tujuan dengan alasan bukan untuk menetap atau mencari nafkah melainkan hanya untuk memenuhi rasa ingin tahu, menghabiskan waktu senggang atau libur serta tujuan-tujuan lainnya (Koen Meyers: 2009).

Indonesia memang kaya akan potensi wisata yang beraneka ragam, mulai dari pantai yang indah, pegunungan, serta peninggalan- peninggalan bersejarah banyak dijumpai di indosesia seperti candi, museum dan tempat bersejarah lainnya. Daerah yang menjadi pusat tujuan wisata salah satunya adalah Bali dengan keindahan alam dan budaya yang masih sangat asri, kental akan kegiatan budaya yang menjadi daya tarik wisata. Selain Bali, daerah tujuan wisata yang banyak diminati wisatawan adalah Yogyakarta. Kota Yogyakarta menjadi daerah tujuan wisata karena Yogyakarta merupakan suatu daerah yang terkenal akan wisata budaya sebagai cagar budaya Jawa. Wisatawan tidak hanya ingin menikmati keindahan alam namun wisatawan pada saat ini lebih cenderung suka mengunjungi tempat- tempat bersejarah untuk lebih mengenal akan budaya daerah setempat dan secara langsung berinteraksi dengan masyarakat. Oeh karena itu berkembang jenis wisata minat khusus yaitu wisata alternatif yang disebut desa wisata. Desa wisata ini menawarkan potensi wisata alam yang masih asri serta kegiatan- kegiatan masyarakat setempat sebagai daya tarik wisata dengan menonjolkan ciri kelokalan budaya setempat dengan harapan desa wisata dapat bersaing dengan tempat wisata lain.
Pengembangan desa wisata ini harus memperhatikan kemampuan dan tingkat penerimaan masyarakat setempat sebagai pihak pengelola. Keminatan serta kepedulian masyarakat untuk mengembangkan desa wisata merupakan ujung tombak dari berkembang atau tidaknya suatu desa wisata. Berkembangnya suatu desa wisata akan memberikan keuntungan pada perekonomian wilayah antara lain pemerataan kesempatan kerja, peningkatan pendapatan masyarakat, serta peningkatan pendapatan daerah.

Yogyakarta adalah salah satu kota di Indonesia yang sukses mengembangkan konsep desa wisata. Salah satu kabupaten yang mengembangkan desa wisata adalah kabupaten Sleman, kabupaten ini kaya akan keindahan alam, kekentalan mempertahankan sosial budayanya, lingkungan yang masih asri dan asli sehingga kabupaten ini layak untuk pengembangan wisata minat khusus yang disebut dengan desa wisata. Banyaknya desa wisata yang terdapat di Sleman menjadikan kabupaten ini menjadi daerah tujuan wisata yang dapat mendatangkan wisatawan. Desa wisata yang ada di Sleman diantaranya adalah desa wisataTurgo, Brayut, Bokesan, Gamplong, Grogol, Kelor, Kembang Arum, Pentingsari, Sidoakur dan masih banyak desa wisata yang ada di Sleman. Masing- masing desa wisata memiliki ciri khas sendiri- sendiri sebagai keunikan dan daya tarik wisata untuk membedakan antar desa wisata.

Sebagai salah satu desa wisata yang terdapat di Sleman khususnya di kecamatan Godean adalah desa wisata Sidoakur, tepatnya di Dusun Jetak II, Kelurahan Sidokarto, Kecamatan Godean, Kabupaten Sleman.Desa ini lebih mengarah ke Budaya dan lingkungan, hal ini di buktikan dengan kegiatan-kegiatan seperti 
penghijauan,pengolahan sampah,pembuatan pupuk kompos, pengembangan biogas dari MCK (mandi, cuci, kakus), dan percobaan pembuatan briket batu bara dari kulit kacang tanah,adapun kegiatan seni budaya antara lain adalah seni karawitan jawa,hadrah,klotekan bambu.

Objek wisata ini juga menawarkan suasana alam, makanan khas (sengek untuk lauk makan), minuman tradisional instan (jamu kunir asem, temulawak, jahe), berbagai macam ikan tawar hasil dari sungai yang ada disekitar dusun, berbagai macam kerajinan hasil daur ulang plastik, serabut kelapa, bambu sebagai souvenir atau cidera mata yang ada di desa wisata Sidoakur.Berbagai potensi dan daya tarik yang dimiliki desa wisata Sidoakur diharapkan dapat memberikan peluang lapangan pekerjaan bagi masyarakat Sidokarto untuk meningkatkan perekonomian masyarakat setempat, sehingga masyarakat yang belum mendapatkan pekerjaan dapat ikut mengembangkan desa wisata Sidoakur. Terciptanya lapangan kerja baru di suatu pedesaan akan memperkecil kemungkinan tingkat pengangguran masyarakat, salah satu caranya adalah dengan memperdayakan masyarakat untuk mengembangkan desa wisata Sidoakur. Penelitian ini akan membahas usaha yang sudah dilakukan baik pemerintah maupun masyarakat Sidokarto untuk mempertahankan desa wisata Sidoakur sebagai desa wisata budaya dan lingkungan melalui pemberdayaan masyarakat setempat.

\section{LANDASAN TEORI}

Tinjuan Umum Pariwisata

\section{Pariwisata}

Pariwisata adalah kegiatan melakukan perjalanan dengan tujuan mendapatkan kenikmatan, mencari kepuasan, mengetahui sesuatu, memperbaiki kesehatan, menikmati olahraga atau istirahat, menunaikan tugas, berziarah dan lain-lain (Koen Meyers: 2009). WTO atau World Tourism Organization mendefinisikan pariwisata adalah kegiatan manusia yang melakukan perjalanan ke dan tinggal di daerah tujuan di luar lingkungan kesehariannya. Pengertian pariwisata tersebut dapat disimpulkan bahwa pariwisata merupakan suatu kegiatan manusia diluar tempat tinggalnya tidak untuk menetap tetapi hanya untuk mendapatkan kenikmatan, kesenangan, dan bukan untuk mencari nafkah atau bukan untuk mendapatkan upah.

\section{Komponen pariwisata}

Komponen pariwisata menurut Pitana dan Diarta:2009 adalah sebagai berikut:

\section{Atraksi Destinasi}

Merupakan elemen- elemen yang terkandung dalam destinasi dan lingkungan di dalamnya yang secara individual atau kombinasinya memegang peran penting dam memotivasi wisatawan untuk berkunjung ke destinasi tersebut. Atraksi destinasi bisa berupa alam, seperti landscape, pantai, pegunungan, iklim, lembah; atraksi buatan, seperti kota bersejarah, taman, resort; atraksi budaya, seperti atraksi teatrikal, drama, festival, museum dan galeri; dan atraksi sosial, seperti kesempatan berbaur dengan masyarakat di daerah tujuan wisata dan ikut mengalami cara hidup bersama mereka.

\section{Fasilitas Destinasi}

Merupakan elemen dalam destinasi atau berhubungan dengan destinasi yang memungkinkan wisatwan tinggal di destinasi tersebut untuk menikmati atau berpartisipasi dalam atraksi yang ditawarkan. Fasilitas destinasi biasa berupa akomodasi, restoran, café dan bar, 
transportasi termasuk penyewaan alat transportasi dan taksi, serta pelayanan lain termasuk toko, salon, pelayanan informasi dan sebagainya

\section{Aksesibilitas}

Merupakan mudah atau sulitnya wisatawan menjangkau destinasi yang diinginkan. Akses berkaitan dengan infrastruktur transportasi, seperti lapangan, terminal bus, dan kereta api, jalan tol, rel kereta api, dan sebagainya. Termasuk didalamnya teknologi transportasi yang mampu menghemat waktu dan biaya untuk menjangkau destinasi wisata tersebut.

4. Imaje (image)

Merupakan ide atau kepercayaan yang dimiliki wisatawan tentang produk atau pelayanan yang mereka beli atau akan beli. Imaje destinasi tidak selalu berdasarkan pengalaman atau fakta tetapi dapat dibentuk sedemikian rupa sehingga menjadi factor motivasi ke destinasi tersebut.

\section{Harga}

Merupakan jumlah keseluruhan dari biaya- biaya selama perjalanan wisata yang mencakup akomodasi, makanan dan minuman, biaya perjalanan dan partisipasi dalam pelayanan yang dikonsumsi selama berada di destinasi yang dituju.

6. Desa wisata

Secara lebih komprehensif menjabarkan desa wisata sebagai suatu wilayah pedesaan yang menawarkan keseluruhan suasana yang mencerminkan keaslian desa, baik dari segi kehidupan sosial budaya, adat istiadat, aktifitas keseharian, arsitektur bangunan, dan struktur tata ruang desa, serta potensi yang mampu dikembangkan sebagai daya tarik wisata, misalnya: atraksi, makanan dan minuman, cinderamata, penginapan, dan kebutuhan wisata lainnya (Fandeli, 2002).Menurut (Hasbullah, 2010) pengertian desa wisata dibagi menjadi dua, yaitu:

a. Desa Wisata: apa bila tamu menginap di suatu objek wisata desa

b. Wisata Desa : apa bila tamu hanya berkunjung di desa

Masyarakat adalah penggerak utama dalam desa wisata. Masyarakat itu sendiri yang mengelola pariwisata tersebut, sehingga tidak ada investor yang bisa masuk untuk mempengaruhi perkembangan desa wisata itu sendiri. Apabila ada suatu desa wisata yang dikelola oleh investor berarti desa tersebut bukanlah desa wisata dalam arti sebenarnya.

\section{Pemberdayaan Masyarakat}

Pemberdayaan masyarakat menurut (Zubaedi: 2007) adalah upaya untuk meningkatkan harkat dan mastabat golongan masyarakat yang sedang kondisi miskin, sehingga dapat melepaskan diri dari perangkap kemiskinan dan keterbelakangan. Pemberdayaan adalah upaya untuk membangun kemampuan masyarakat dengan mendorong, memotivasi dan membangkitkan kesadaran akan potensi yang dimiliki dan berupaya untuk mengembangkan potensi itu menjadi tindakan nyata.

\section{METODE PENELITIAN}

Metode yang digunakan dalam penelitian ini adalah metode kualitatif diskriptif. Pendekatan kualitatif adalah suatu proses penelitian dan pendalaman yang berdasarkan pada metodologi yang menyelidiki suatu fenomena sosial dan masalah manusia (Utama \& Mahadewi:2012). Metode kualitatif diskriptif adalah menganalisis hanya sampai pada taraf diskripsi, yaitu menganalisis dan menyajikan fakta secara 
sistematik sehingga dapat lebih mudah untuk difahami dan disimpulkan. (Azwar: 2010).

\section{Tehnik Pengumpulan Data}

Tehnik pengumpulan data menurut (Bagus dan Mahadewi, 2012) ada beberapa tehnik pengumpulan data, dalam penelitian ini oenulis menggunakan tehnik pengumpulan data sebagai berikut:

a. Metode Observasi

Menurut Nawawi (2005) observasi adalah cara pengumpulan data yang dilakukan dengan cara mengamati dan mencatat secara sistematisk gejala-gejala yang diselidiki. Penulis mendatangi langsung desa wisata Sidoakur yang berlokasi di Dusun Jetak III,Sidokarto, Godean, Sleman. Penulis mengamati desa wisata tersebut dengan berbagai potensi unggulan sehingga dapat dijadikan sebagai desa wisata. Observasi dilakukan penulis selama kurang lebih 3 bulan, hal ini dilakukan supaya dalam penelitian ini penulis mendapatkan hasil yang akurat

b. Metode Wawancara

Menurut Bagus dan Mahadewi (2012) Wawancara adalah proses tanya jawab dalam penelitian yang berlangsung secara lisan. Tehnik wawancara ini banyak dilakukan sebab tehnik ini merupakan salah satu bagian terpenting dalam setiap penelitian. Tanpa wawancara penelitian akan kehilangan informasi yang hanya dapat diperoleh dengan bertanya langsung kepada responden. Untuk memperkuat data riset maka penulis melakukan wawancara langsung pada pengelola desa wisata yang sekira dapat dijadikan informan untuk mengumpulkan data- data penelitian. Penulis juga melakukan wawancara kepada beberapa masyarakat setempat yang notabennya adalah masyarakat yang ikut serta dalam pengembangan desa wisata Sidoakur.

\section{c. Metode Dokumentasi}

Tehnik pengumpuan data dengan dokumentasi adalah mengambil data yang doperoleh melalui dokumen- dokumen (Bagus dan Mahadewi:2012)

\section{Instrumen Penelitian}

Dalam penelitian kualitatif ini, menggunakan dua instrument yaitu:

1. Instrumen utama, instrument utama dalam penelitian ini adalah peneliti sendiri, dimana peneliti sebagai human instrument berfungsi menetapkan fokus penelitian, memilih sumber data, mengumpulkan data, menilai kualitas data, menganalisis dan menafsirkan data dan membuat simpulan.

2. Intrument pelengkap, setelah fokus penelitian di lapangan menjadi jelas dikembangkan instrumen penelitian sederhana lain guna melengkapi dan membandingkan data, yakni; questioner, buku catatan, tape recorder, handycam, kamera dan lain sebagainya

Peneliti sebagai instrumen utama dalam menentukan kualitas penelitian. Oleh karena itu peneliti harus benar- benar divalidasi mengenai proses pengambilan data supaya informasi yang didapatkan peneliti dapat untuk dipertanggungjawabkan dan kredibel.

\section{Tempat dan Waktu Penelitian}

a. Tempat Penelitian

Penelitian ini dilakukan disebuah desa wisata yang berlokasi di Dusun Jetak III, Sidokarto, Godean, Sleman, Yogyakarta. Desa wisata ini diberi nama desa wisata Sidoakur dan merupakan salah satu desa wisata dengan cara pengembangan desa wisata melibatkan masyarakat setempat.

b. Waktu Penelitian 
Penelitian kualitati membutuhkan waktu yang relatif lama karena penelitian kualitatif merupakan penelitian yang bersifat penemuan bukan sekedar pengujian hipotesis. Penulis membutuhkan waktu kurang lebih 6 bulan yaitu pada bulan September 2016- Februari 2017.

c. Tehnik Analisa Data

Data yang telah diperoleh akan di analisa dengan menggunakan metode kualitatif. Metode kualitatif ini akan memberikan gambaran yang represenatif dan lebih detail tentang sebuah kasus. Neuman (1997). Analisa yang didapat dari penelitian ini tidak mendasarkan pada perhitungan kuantitatif, akan tetapi lebih kepada kemampuan peneliti dalam menghubungkan data dan informasi yang diperoleh.

\section{HASIL DAN PEMBAHASAN}

\section{Deskripsi Objek Wisata}

Godean adalah sebuah kecamatan di Kabupaten Sleman, ProvinsiDaerah Istimewa Yogyakarta, Indonesia. Kecamatan Godean berada di sekitar 10 km sebelah Barat daya dari Ibukota Kabupaten Sleman. Lokasi ibu kota kecamatan Godean di Jl. Godean Km.10, Sleman berada di 7.76774` LS dan 110.29336` BT. Kecamatan Godean mempunyai luas wilayah 2.684 Ha. Bentangan wilayah di Kecamatan Godean berupa tanah yang datar dan sedikit berbukit. Desa wisata merupakan kawasan pedesaan yang memiliki beberapa karakteristik khusus, baik seni budayanya atau penghasil sebuah karya. Beberapa faktor pendukung berupa makanan khas, sistem sosial, dan alam serta lingkungan yang masih asri. Salah satu desa yang memiliki kristeria tersebut salah satunya berada di Kabupaten Sleman, yakni di Desa Wisata Sidoakur, Jethak. Desa ini terletak di $22 \mathrm{Km}$ kearah selatan
Kota Kabupaten Sleman yakni didesa Sidokarto, Kecamatan Godean, Kabupaten Sleman. Dari Tugu Yogyakarta lurus kearah barat dan akan menemui desa Sidokarto.Sidokarto adalah desa di kecamatan Godean, Sleman, Daerah Istimewa Yogyakarta, Indonesia. Pada mulanya Desa Sidokarto merupakan wilayah yang terdiri dari 3 (tiga) Kelurahan, masing-masing adalah Kelurahan Rewulu, Wirokraman, dan Klajoran. Berdasarkan maklumat Pemerintah Daerah Istimewa Yogyakarta yang diterbitkan tahun 1946 mengenai Pemerintahan Kelurahan, maka 3 (tiga) Kelurahan tersebut kemudian digabung menjadi 1 Desa yang otonom dengan nama Desa Sidokarto. Desa Wisata Sidoakur diresmikan pada 21 Maret 2009, merupakan Desa Wisata yang berlokasi di padukuhan Jethak II, Kelurahan Sidokarto, Kec. Godeab, Kab. Sleman, Yogyakarta. Desa Wisata ini menyediakan potensi wisata berupa homestay rumah tradisional, kesenian hadroh, musik kentongan kelompok ronda, macapat, pengolahan limbah menjadi kompos, produk makanan dan jamu serta kerajinan dari hasil daur ulang limbah domestik. Batas wilayah desa wisata Sidoakur adalah sebagai berikut:

Sebelah Utara : Kecamatan Mlati

Sebelah Timur : Desa Sidomoyo, Desa Sidoarym

Sebelah Selatan : Desa Sidomulyo Sebelah Barat : Desa Sidoagung.

Desa wisata Sidoakur adalah salah satu dari 39 desa wisata yang ada di kabupaten Sleman, Yogyakarta. Desa wisata ini menyandingkan potensi wisata budaya, serta lingkungan. Potensi tersebut dipadukan dengan system organisasi desa yang sudah berjalan sistematis. Organisais tersebut berjalan dengan melibatkan semua segmen usia warga. Desa wisata Sidoakur 
memiliki luas areal sebesar 38 ha. Luas tersebut dibagi menjadi lima RT (Rukun Tangga) dan terdiri dari 251 KK (Kepala Keluarga), dengan jumlah penduduk sekitar 1300 jiwa.

Sebelum menjadi desa wisata, Jethak merupakan kawasan yang acapkali dipenuhi dengan sampah plastik. Selain persoalan plastik desa Jethak juga pernahmerasakan berkurangnya debit air tanah. Upaya- upaya baru digerakkan masyarakat dengan keikutsertaan desa dalam mengikuti lomba Klompemncapir (kelompok pendengar, pembaca dan pirsawan) yang popular pada dekade awal tahun 90- an. Dalam lomba bertingkat nasional ini, Desa Jethak berhasil meraih juara umum pada tahun 1991. Nama kelompok dalam keikutsertaan lomba ini diberi nama Sidoakur. Dari perlombaan itulah nama Sidoakur didapat dan digunakan hingga saat ini. Seiring dengan keberhasilan tersebut, kesadaran warga akan kebersiahan juga semakin meningkat. Upaya- upaya revitalisasi potensi dilakukan degan melibatkan semua lapisan usia.

Memasuki tahun 2008, desa ini kembali mengikuti beberapa kejuaraan lingkungan dan berhasil menyabet gelar pemenang. Salah satu kejuaraan yang mempengaruhi motivasi warga adalah program Green and Clear yang digelar salah satu perusahaan multinasional. Kejuaraan yang diraih, desa Jethak berhasil mendapakan predikat Best of The Best Kategori desa yang Berkepadatan Rendah. Keberhasilan tersebut motivasi dan kepercayaan warga semakin menguat, hingga akhirnya pada awal tahun 2009, desa Jethak resmi menjadi desa wisata budaya dan lingkungan. Desa wisata ini tidak melepaskan nama yang sudah menjadi sejarah perjalan desa wisata tersebut yang mana desa wisata ini tetap menggunakan nama desa wisata Sidoakur.
2. Usaha pemerintah maupun masyarakat Sidokarto dalam mempertahankan desa wisata Sidoakur sebagai desa wisata Budaya dan Lingkungan melalui Pemberdayaan Masyarakat

Secara umum desa wisata adalah sebuah kawasan pedesaan yang memiliki beberapa karakteristik khusus untuk menjadi daerah tujuan wisata. Di kawasan ini, penduduk yang masih memiliki tradisi dan budaya yang relative masih asli, selain itu beberapa faktor pendukung seperti makanan khas, system pertanian dan system sosial turut mewarnai sebuah kawasan desa wisata. Di luar faktor tersebut, alam dan lingkungan yangmasih asli dan terjaga merupakan salah satu faktor terpenting dalam kawasan daerah tujuan wisata. Kriteria wisata tersebut semuanya dimiliki pada desa wisata Sidoakur. Potensi yang dimiliki desa wisata Sidoakur sebagai desa wisata berupa keistimewaan seni dan budaya yaitu seni karawitan, gejog lesung, karawitan, klotekan, sholawat, macapat, hadroh serta panembarama. Selain kesenian, nilai- nilai tradisi budaya masih dipegang erat warga desa. Salah satu yang terlihat hingga pada saat ini adalah kegiatan kegotongroyongan warga dari hasil pembangunan desa.

Semua dari pembangunan warga desa Jethak merupakan buah dari budaya gotong royong warga yang terus menerus dan melingkuppi semua lapisan masyarakat baik anak- anak, pemuda dan orang tua. Masyarakat memiliki system komunikasi dan koordinasi yang berjalan sistematis dan terbuka yang kemudian muncul rencana aplikasi dan sosialisasi dilakukan. Nuansa gotong royong dan komunikasi yang continue membuat warga akan merasa sungkan jika tidak ikut serta dalam pengembangan desa. Selain budaya dan 
kesenian, desa wisata Sidoakur juga memiliki dua rumah khas jawa yang menjadi tempat penyambutan tamu. Kedua rumah tersebut adalah rumah limasan dan rumah joglo miliki masyarakat setempat yang berdiri sejak tahun 1941. Kedua rumah tersebut masih asli dari awal pembangunannya hanya beberapa renovasi tanpa merubah sedikit pun dari bangunan rumah tersebut.

Usaha yang dilakukan pemerintah kabupaten sleman dalam pengembangan desa wisata Sidoakur adalah pemerintah Sleman memberikan bantuan dana melalui program Program Nasional Pemberdayaan Masyarakat Mandiri (PNPM) Mandiri Pariwisata. Pemerintah kabupaten Sleman berharap dengan adanya bantuan dana dan perhatian dari pemerintah kabupaten, desa wisata Sidoakur menjadi desa wisata unggulan supaya dapat bersaing dengan desa wisata lain.

Selain bantuan dari pemerintah usaha masyarakat desa wisata Sidoakur dalam pengembangan desa wisatanya adalah melalui pemberdayaan masyarakat dengan pengelolaan lingkungan dan kebudayaan. Pengelolaan lingkungan dan kebudayaan yang dapat dilakukan masyarakat setempat adalah:

\section{Penghijauan}

Kawasan hijau yang tersebar merata dilingkungan masyarakat juga bernilai ekonomis. Beberapa pohon yang ditanam masyarakat jika sudah tumbuh besar dapat dijual sehingga mampu menumbuhkan tingkat perekonomian masyarakat Sidokarto. Pengelolaan limbah dan sampah rumah tangga sudah mengakar sedemikian rupa pada seluruh masyarakat Sidokarto demi menjaga kelestarian dan kebersihan lingkungan. Di setiap rumah warga tersedia komposter bahkan warga sudah dibekali dengan pengetahuan yang cukup tentang pemisahan sampah organik dan anorganik. Setiap keluarga memiliki tabungan sampah yang disetorkan ke desa secara rutin setiap minggunya dan kemudian sampah- sampah tersebut dijual pada pengepul untuk di daur ulang menjadi beragam produk sehingga warga dari sampah tersebut warga mendapatkan uang. Sebagian sampah dapat didaur ulang oleh warga untuk pembuatan kerajinan berbahan dasar sampah plastik. Kerajinan yang dihasilkan dari sampah platik diantaranya adalah tas, tempat pensil, sandal, dan dompet unik. Selain sampah plastic, sampah organic seperti serabut kelapa juga digunakan untuk bahan dasar kerjinan topeng monyet. Warga saat ini mulai membuat briket arang yang mana briket arang ini dapat menghasilkan api berwarna biru seperti pada api elpigi yang dapat bertahan selama 1,5 jam. Seluruh proses pengelolaan limbah dan pembuatan kerajinan tersebut melibatkan warga terutama para pemuda. Sementara ini pengelolaan limbah rumah tangga juga diintegrasikan agar bisa digunakan kembali yaitu dengan metode pembuatan biogas. Desa Sidoakur memiliki system senimas (sanitasi masyarakat). Salah satu buah dari senimas adalah adanya MCK (mandi, cuci, kakus) plus yang digunakan warga seharihari. Limbah rumah tangga yang ditampung dalam MCK plus kemudian ditampung dalam tabung bawah tanah. Penampungan tersebut secara otomatis akan menghasilkan uap limbah yang telah berubah menjadi gas metana. Gas ini yang kemudian disalurkan ke selang- selang dan bisa digunakan sebagai bahan bakar gas (biogas).

1. SPAH (Sistem Penyimpanan Air Hujan).

SPAH merupakan antisipasi warga desa Sidoakur Jethak untuk menghindari kelangkaan air sebagaimana yang pernah dialami oleh warga. SPAH dilakuakn 
dengan dua cara yaitu dengan pembuatan biopori serta sumur resapan. Biopori adalah lubang- lubang sedalam kurang lebih 1,5 meter yang diborkan ke tanah. Melalui biopori tersebut air hujan disalurkan ke dalam sumur resapan yang lebih besar.

2. Pertanian dan perikanan organik.

System pertanian organik merupakan pengelolaan lingkungan yang paling akhir diterapkan desa Sidoakur. Pertanian berbasis pada penggunaan benih, pupuk serta pestisida organic yang dihasilkan dari pengolahan limbah maupun pembibitan dan pembenihan alami. System ini memberikan dampak positif bagi warga desa yang sebagian besar bermata pencaharian petani bisa memanen tanaman padi yang jika dimasak lebih bertahan lama (hingga 3 hari). Penggunaan pupuk sangat membantu keuangan petani. Warga dapat menghemat uang lebih besar dengan menggunakan pupuk organik. Pupuk organik yang diperoleh dari pengkomposan sampah organik, limbah cair serta air kelapa dikelola dan diolah oleh warga desa.

\section{KESIMPULAN}

Desa wisata Sidoakur merupakan desa wisata yang terletak di $22 \mathrm{Km}$ kearah selatan Kota Kabupaten Sleman yakni didesa Sidokarto, Kecamatan Godean, Kabupaten Sleman.Secara umum desa wisata adalah sebuah kawasan pedesaan yang memiliki beberapa karakteristik khusus untuk menjadi daerah tujuan wisata. Di kawasan ini, penduduk yang masih memiliki tradisi dan budaya yang relative masih asli, selain itu beberapa faktor pendukung seperti makanan khas, system pertanian dan system sosial turut mewarnai sebuah kawasan desa wisata. Di luar faktor tersebut, alam dan lingkungan yangmasih asli dan terjaga merupakan salah satu faktor terpenting dalam kawasan daerah tujuan wisata. Potensi yang dimiliki desa wisata Sidoakur sebagai desa wisata berupa keistimewaan seni dan budaya yaitu seni karawitan, gejog lesung, karawitan, klotekan, sholawat, macapat, hadroh serta panembarama. Selain kesenian, nilai- nilai tradisi budaya masih dipegang erat warga desa. Salah satu yang terlihat hingga pada saat ini adalah kegiatan kegotongroyongan warga dari hasil pembangunan desa. Usaha yang dilakukan pemerintah kabupaten sleman dalam pengembangan desa wisata Sidoakur adalah pemerintah Sleman memberikan bantuan dana melalui program Program Nasional Pemberdayaan Masyarakat Mandiri (PNPM) Mandiri Pariwisata. Pemberdayaan masyarakat yang terlihat adalah dengan pengelolaan lingkungan dan kebudayaan dilakuakan warga dengan cara penghijauan, SPAH (Sistem Penyimpanan Air Hujan), serta pertanian dan perikanan yang dikelola oleh seluruh lapisan masyarakat dengan berbagai usia.

\section{DAFTAR PUSTAKA}

Azwar, Saifuddin. 2010. Metode Penelitian. Yogyakarta: Pustaka Pelajar

Fandeli, C. 2002. Perencanaan Kepariwisataan Alam. Yogyakarta: Fakultas KehutananUniversitas Gadjah Mada

Hasbullah, 2010. Teknologi tepat guna Agroindustri kecil Sumatera Barat IlmuPengetahuan, Teknologi dan Industri Sumatera

Barat.http://www.iptek.net.id/ind/ warintek $/ ? \mathrm{mnu}=6 \& \mathrm{ttg}=6 \& \mathrm{doc}=6 \mathrm{a} 6$. Diakses Pada Tanggal 20 Februari 2016

L. Neuman (1997), Social Research Methods: Qualitative and Quantitative Approaches in Social 
Works. New York: Columbia University

Mahadewi, E. Ni Made dan Rai Utama, I.G. Bagus. 2012. Metode Penelitian Pariwisata dan Perhotelan.Yogyakarta. Penerbit: CV Andi Offset.

Meyers, Koen\&Zalukhu, Sukawati. (2009).

Panduan Dasar Pelaksanaan Ekowisata. Jakarta: Unesco Office.

Nawawi, Hadari. 2005. Metode Penelitian Bidang Sosial. Yogyakarta. Gadjah Mada University Press

Pitana, I Gde. dan Surya Diarta, I Ketut. 2009. Pengantar Ilmu Pariwisata. Yogyakarta: Penerbit Andi.

Zubaedi. (2007). Wacana Pembangunan Alternatif: Ragam Perspektif Pengembangan dan Pemberdayaan Masyarakat. Yogyakarta: Ar- Ruzz. 